Article

\title{
Public Participation in Designing the Recycling Bins to Encourage Recycling
}

\author{
Kiriaki M. Keramitsoglou * (iD) and Konstantinos P. Tsagarakis \\ Business and Environmental Technology Economics Laboratory (BETECO), Department of Environmental \\ Engineering, Democritus University of Thrace, 67100 Xanthi, Greece; kkeramit@env.duth.gr \\ * Correspondence: johnkiki@hol.gr; Tel.: +30-69-7680-9249
}

Received: 28 February 2018; Accepted: 13 April 2018; Published: 18 April 2018

\begin{abstract}
Recycling bin design has been shown to be important in guiding and changing waste management practices. The top-down imposition of recycling scheme components, the various colour signage, the different types of recycling bins per material even in the same city, and in light of the limitations cited in the relevant literature, our contribution examines the citizens' involvement in designing recycling bins. Analyzing the responses of 757 participants randomly selected, we initially defined design variables, i.e., shape, colour, and type of lid and insert slot. The next step was to design six bins per recyclable and non-recyclable material, which were printed in a card in a random order. In total, 12 cards were evaluated by 430 residents of a typical Greek town without previous experience in recycling; personal interviews were conducted and citizens gave a score on a scale from one to six. The results highlight the public preference for specific lids and insert slots, and a rectangular shape for all the materials apart from glass and compostables for engaging in recycling. In addition, the results suggest that a connection might exist between the colour of the recyclable material and the colour of the bin. When there is no particular bin colour preference for a material such as plastic or packages, various hues of orange, yellow, or purple dominate. A reward phrase or environmental message printed on the bins could encourage recycling.
\end{abstract}

Keywords: design; public participation; recycling bins; recycling

\section{Introduction}

The design of the recycling bin is considered a critical issue in waste management as a mediating device between households and waste services. This role is invested with particular cultural, social, and technical connotations. While putting all municipal solid waste in one container leaves the control of their management to the waste services (Figure 1a), recycling bins shift some control to households (Figure 1b); they undoubtedly represent a visual reminder of our environmental responsibility. Their development and introduction in quotidian life has contributed to a reconsideration of waste management, changing waste practices, modifying behaviour, shifting the boundaries between private individual and public collective effort, and assisting in changing environmental ethics [1-7].

Effective recycling mostly depends on proper infrastructure [8,9]. Thus, it is common to promote a recycling scheme by providing free means of collection such as recycling containers and bags or boxes to motivate users to sort out their waste prior to visiting a recycling station [10-15]. In addition, the recycling bins with their visual impact can function as the best advertisement for a recycling scheme and their distinctive appearance can serve as a visual signal of the citizens' ethical obligation to participate in recycling activities [7,16-18]. Finally, the effective promotion, provision, and availability of appropriate recycling bins can significantly increase the participation levels in a recycling programme and support its success [19-26]. The lack of appropriate storage facilities was a contributing factor 
to poor waste management in the city of Dar es Salaam, Tanzania [27], and the limited bins to non-participation of the community in recycling in Putrajaya, Malaysia [28].

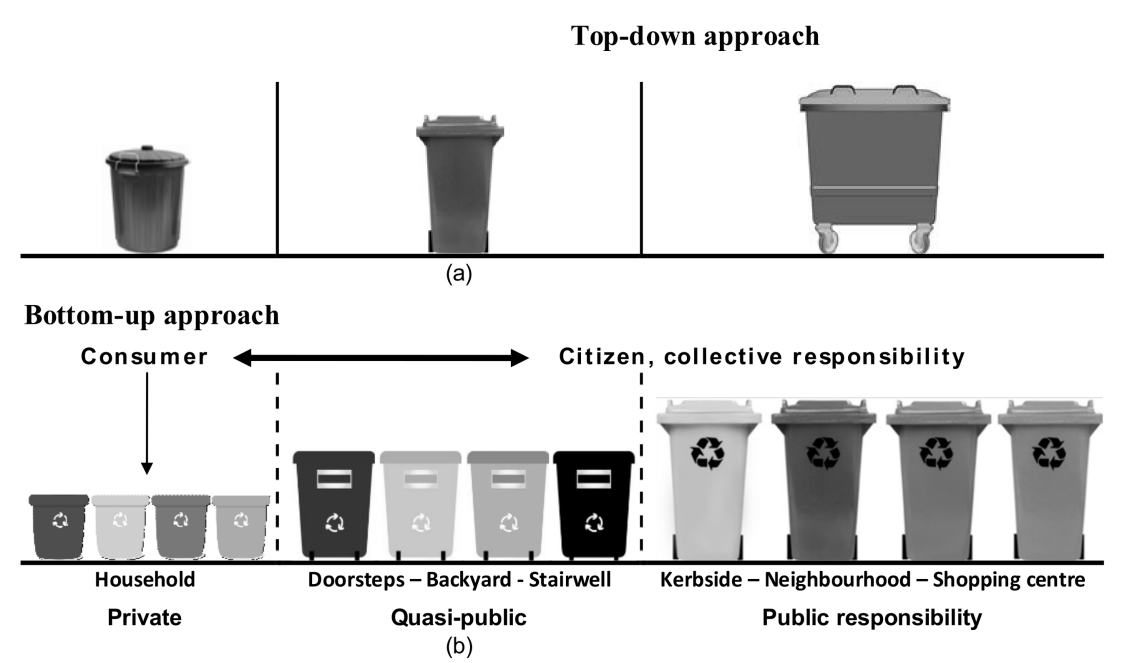

Figure 1. Two approaches in waste collection: (a) the top-down and (b) bottom-up approach in waste collection.

The number of recyclers is crucial for the successful implementation of a recycling scheme, but not enough; how effectively the citizens participate constitutes another important factor [29-31]. The colour-coded bins can significantly contribute to sort high quality recyclables without contamination, maximise convenience, and minimise effort and time spent in identifying the appropriate collection container. However, citizens do not always approve the appearance and design of recycling bins; for instance, while the council of the city of Sheffield, UK, provided blue bins for the city's kerbside paper recycling scheme, householders characterised the colour of the bin as "environmentally offensive". The colour of the bin was reported as the main reason for non-participation in the scheme and therefore it had to be redesigned [32]. The residents of Brixworth criticised the blue and red boxes for their unsuitable design because of trapping rainwater, which had an impact on recycling rates during wet days [33]. The inappropriate design of collection bins used in various places in Puducherry, India, and their small size resulted in a poor collection efficiency [34], as did the inadequate capacity of household recycling bins in Ontario, Canada [35]. According to Fan (2014), the recycling and non-recycling multi-bins installed everywhere in China failed to encourage public participation in waste separation [36]. Changing the look of the receptacles might increase recycling rates and decrease littering and fly-tipping in the Limerick region, Ireland [37].

Although the recycling containers play a key role in recycling programmes, the impact of their design on recycling rates has not yet been thoroughly explored [38]. Questions which still remain open relate to what recycling bins can reframe everyday waste practices, encourage people to act morally and responsibly, change the recycling attitude, turning it into unintentional and spontaneous behaviour, and result in lower levels of missed collections, thus preventing recycling misplacements. Municipal authorities traditionally impose a top-down recycling scheme without the participation of the public in decision making on particular components of its implementation. Previous research indicated that colours, symbols, or logos, which have been established with the participation of the public in the design process, better affect the intended users' behaviour than those imposed top-down [39,40].

The present research aims to explore firstly, the citizens' preference for particular design parameters of various recycling bins and secondly, their opinion on deciding what bin is appropriate for each material. To this end, in the second stage, we analysed data collated from a small provincial town without a recycling scheme. This methodology approach, however, could also be implemented in other regions or countries. 
A web search reveals a plethora of recycling bins, which could be categorised according to their design and aesthetic variables such as capacity, construction material, shape or form, and colour. These could be summed up as follows:

(i) Capacity: recycling bins come in various sizes depending on their use; i.e., small bins for domestic use, larger ones for schools, offices, and business premises, and higher capacity bins for recycling in public facilities; for instance, the large containers at Swedish recycling stations [41]. An incentive for the residents of Austin, Texas, to recycle is the provision of blue recycling bins that are a lot bigger than the green garbage bins [42]. An eight-compartment bin for recycling the seven types of plastic and blended polymer was designed as an educational tool in Hong Kong. The various sizes of compartments served the required storage volume and the different plastic amounts consumed locally [43].

(ii) Construction material: plastic constitutes the most common material, but recycling bins can also be made of aluminium, metal, or wood.

(iii) Shape and form: all geometric shapes can be found; i.e., a rectangle, cylinder, bell, cube, or polyhedron, and even the shape of a frog at a Japanese underground station [44].

(iv) Colour: the colour of bins usually provides information about a particular recycling material; it is usually blue, green, yellow, red, orange, white, beige, and grey. There are also transparent coloured or plain transparent recycling bins, like the recycling bins at Shibuya station, Tokyo. Recycling bins may contribute to the prevention of overconsumption, and the promotion of sustainable living and responsible recycling; nevertheless, if the level of contamination inside the transparent bins is high, it is more likely that the user will dispose of the wrong waste inside. However, so far, no study has confirmed either view [45,46]. Recycling bins might also be covered with lids of different bright colours or have openings with coloured borders and bear various graphics or logos. Moreover, recycling bins of particular artistic interest exist, which demonstrate an attempt to encourage recycling through art. Examples include the recycling bins decorated with works of photo artists in commercial zones and heavy traffic areas in Toronto [47], or the artistic recycling bins placed around the scenic Bloomington campus [48] or in Great Barrington, Western Massachusetts [49] and at a recycling station in Afula, Israel [50].

(v) Signage: the inclusion of signage on bins has recently become mandatory by law in New York City. The consistent colour and shape, the image of items to be disposed, the necessary textual description, and the appropriate size and placement are key elements for a successful sign, which provides clear information about the proper use of a recycling bin and assists in the reduction of contamination [51-53].

There is not a universal rule for the colour of the recycling bin, lids, and labels in relation to the recycling material. Moreover, there might be separate bins for glass bottles according to their colour, i.e., white bins for clear bottles, green for green ones, and red-brown for dark colour glass. The containers for non-recyclables are usually of dark hues. Therefore, there are green bins for paper, glass bottles, and cans or compost. Recycling bins, lids, and labels of different colours and various shapes for a recycling material can be found even within the same city, region, or country.

The shape and the colour of the bin, lid, and label should provide information about the recycling of a particular material. Figures S1 and S2 present paper recycling bins of various colours and shapes and different recycling material bins at recycling sites in Greece (Supplementary Material). A closer examination reveals that there are several types of recycling bins according to material; the paper recycling bin can be blue, light blue, green, yellow, or white; the plastic recycling bin might come in a red or yellow colour; the package recycling bin can be grey or brown; the mixed glass recycling bin might be blue, black, or green; and the aluminium and metal recycling bin can be yellow, light blue, or dark green. 
Moreover, a review of various studies indicates that the same meaning, message, and information are provided by different colours in different recycling programmes (Table 1). For instance, the recycling schemes for package waste recovery, implemented in 33 countries, aim to apply the best practices, using bins of different colours. These programmes use the "green dot" symbol, a trademark internationally recognisable which has contributed to the harmonisation of national measures for waste management with the principles of EU Directive 2004/12/EC on packaging and packaging waste, and to the successful attribution of responsibility to producers [54,55]. Thus, a German tourist in Athens might have difficulty finding a bin to recycle his/her newspaper because of the different colour, which is yellow instead of the familiar blue, or to recycle the packaging items due to the different colour, namely blue instead of the familiar yellow [56-59]. However, paper is discarded in blue recycling bins, compostable waste in green or brown bins, and non-recyclables in black or dark grey bins in most countries.

The most important function of colour is to convey information visually and influence behaviour changes towards intention to recycle. Yet, colour perception depends on several factors such as experiences, imagery, memory, and cultural background [60,61]. Even though colours have different meanings across different cultures, these meanings can change over time and in the case of recycling, different colour messages might cause confusion and sorting mistakes, thus not raising awareness of what type of waste goes into which bin. Besides, familiarity with the recycling infrastructure of a scheme constitutes a crucial factor in participation, while the doubt of putting waste into the wrong bin is another reason for not recycling [62].

Additionally, the openings of containers designed for the collection of glass or plastic bottles and beverage cans are almost always a round shape; for newspapers and paper collection, they come in a rectangular shape of various sizes and for plastic or other materials in a square or rhomboid shape. When the recyclables must be protected by insects, rain, or snow, there are no openings; instead, the containers have lids which open and close safely. There are always instructions on the bin in the native language and in English or a sketch or painting of the recycling material on the bin, i.e., bottles, plastic, packages, or paper. 
Table 1. Colours of recycling bins per material in various schemes and countries.

\begin{tabular}{|c|c|c|c|}
\hline Materials & Colours & Place/Scheme/Country & References \\
\hline \multirow{6}{*}{ Paper } & \multirow[b]{2}{*}{ Blue } & Palmerston Massey University campus/New Zealand & {$[62,63]$} \\
\hline & & $\begin{array}{c}\text { Various cities/Green Dot/Germany } \\
\text { Hong Kong }\end{array}$ & $\begin{array}{l}{[57]} \\
{[43]}\end{array}$ \\
\hline & Red & Brixworth/UK & [64] \\
\hline & Orange & Mashhad city/Iran & [65] \\
\hline & Yellow & Athens/Greece & [56] \\
\hline & Brown & Green-dot/various cities/Cyprus & [66] \\
\hline \multirow{4}{*}{ Plastic } & Yellow & Palmerston Massey University campus/New Zealand & {$[62,63]$} \\
\hline & Red & Mashhad city/Iran & [65] \\
\hline & Brown & Hong Kong & [43] \\
\hline & Blue & Green-dot/various cities/Cyprus & [66] \\
\hline \multirow{9}{*}{$\begin{array}{l}\text { Commingled } \\
\text { recyclables }\end{array}$} & Orange & Fuchu/Japan & [67] \\
\hline & \multirow{2}{*}{ White } & Puducherry/India & [34] \\
\hline & & Azcapotzalco campus of UAM-A/Mexico & [68] \\
\hline & Green & Green bin system/Germany & [69] \\
\hline & Yellow & Berlin/Yellow Bin plus/Germany & [70] \\
\hline & \multirow{4}{*}{ Blue } & Brixworth/UK & [64] \\
\hline & & Barnet London Borough/UK & [71] \\
\hline & & PAYT/Ontario/Canada & [35] \\
\hline & & Los Angeles/California USA & [72] \\
\hline \multirow{2}{*}{ Packages } & Blue & Various cities/Green Dot/Greece & [73] \\
\hline & Yellow & Various cities/Green Dot/Germany & [57] \\
\hline Aluminum cans & Yellow & Hong Kong & [43] \\
\hline \multirow{11}{*}{ Compostable waste } & \multirow{6}{*}{ Green } & Fuchu/Japan & [67] \\
\hline & & Puducherry/India & [34] \\
\hline & & Wealden/CROWN/UK & [74] \\
\hline & & Rushcliffe/UK & [75] \\
\hline & & Barnet London Borough/UK & [71] \\
\hline & & Los Angeles/California USA & [72] \\
\hline & \multirow{3}{*}{ Brown } & Dorset/UK & [76] \\
\hline & & Brixworth/UK & [64] \\
\hline & & Various cities/Green Dot/Germany & [57] \\
\hline & Orange & Oregon State University Academic libraries & [77] \\
\hline & Grey & Green bin system (Germany) & [69] \\
\hline \multirow{8}{*}{ Waste } & \multirow{5}{*}{ Black } & Wealden/CROWN/UK & [74] \\
\hline & & Brixworth/UK & [64] \\
\hline & & Palmerston Massey University campus/New Zealand & {$[62,63]$} \\
\hline & & Puducherry/India & [34] \\
\hline & & Barnet London Borough/UK & [71] \\
\hline & \multirow{2}{*}{ Grey } & Rushcliffe/UK & [75] \\
\hline & & Various cities/Green Dot/Germany & [57] \\
\hline & Red & Azcapotzalco campus of UAM-A/Mexico & [68] \\
\hline \multirow{2}{*}{ Food residuals } & Green & Palmerston Massey University campus/New Zealand & {$[62,63]$} \\
\hline & Brown & Barnet London Borough/UK & [71] \\
\hline
\end{tabular}


Overall, manufacturers, collection companies of recyclables, municipalities, or other governmental agencies share the common aim of promoting recycling by providing recycling bins, which do not require users to spend time thinking about which is the appropriate bin for disposing each recyclable material. Thus, the problem of designing a recycling bin should be approached within the context of values in design parameters which maximise user utility. The designer and producer have to take into account the "voice" of the users and explore their preferences $[78,79]$. Based on the literature and our own experience, we have created Figure 2 with various demands, desires, and needs a recycling bin should meet. The present research mainly focuses on the recycler's convenience and the practical and functional aesthetics of the recycling bin.

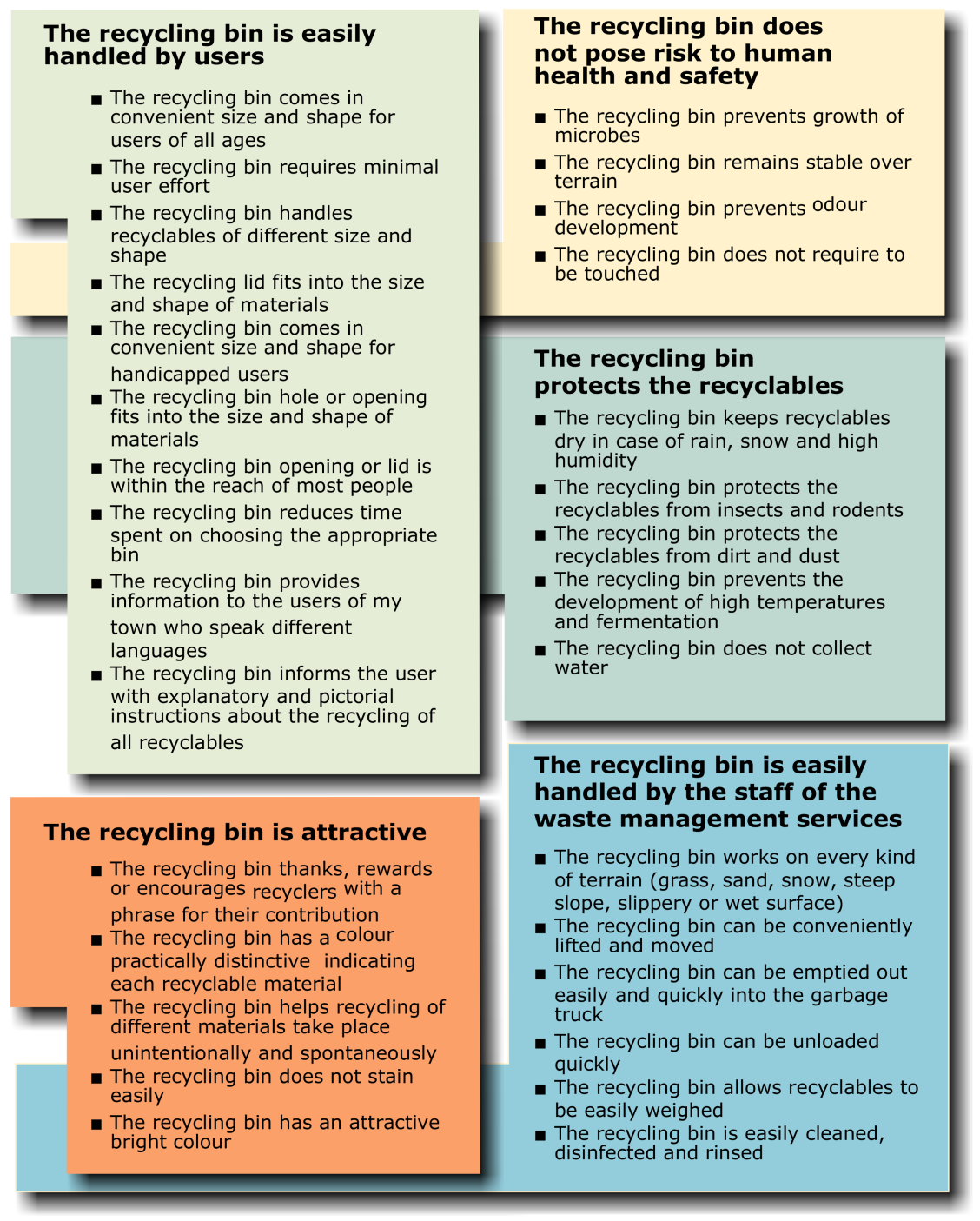

Figure 2. A list of design issues for recycling bins.

\section{Materials and Methods}

The research was conducted in two stages, one exploratory and one validation stage. Two fully structured questionnaires were designed to meet the research aims. The first questionnaire consists of two parts; the first one asked participants to select a type of bin and bin slots from a list of various types of bins and slots printed in the questionnaire for each recyclable and non-recyclable material, as well as a colour from a printed typical Microsoft colour palette (see Figure S3 of Supplementary material); it further asked them about the type of bin lid and multi-bin they would prefer; how the recycling 
instructions should be provided and in what languages; whether the bin should be made of transparent material; and finally, it asked them to write a phrase which would encourage recycling behaviour. The second part included questions about the respondents' socio-economic status. The participants came from Thrace, a region in North-Eastern Greece.

Taking into account the findings as defined by the exploratory stage, we designed six bins per recyclable and non-recyclable material, which were printed in a card in a random order. More than six choices would lead people to a non-perfect evaluation of alternatives, defined as the paradox of choice $[80,81]$. We asked residents to give a score for each design ranging from one to six. The target population of this phase consisted of the residents of Didimoticho, a typical provincial Greek town with a total population of 9367 inhabitants (2011 census), with no previous experience in recycling.

\section{Results}

This section summarizes findings of the exploratory and the validation stage. Emphasis is given to the outcome of the exploratory stage and the validation of those findings, but all primary exploratory data analysis is available in the Supplementary Material of this paper.

\subsection{Exploratory Stage}

The sample of the exploratory stage consisted of 757 participants (age: $M=34.27, S D=13.891$; gender: $42.3 \%$ male and $57.7 \%$ female). There were some missing values as participants did not respond to all the questions. Figures S14 to S22 present the six bins which were designed taking into account the findings of this stage (see Figures S4-S13 of Supplementary Material). We designed non-transparent bins (as preferred by $68.18 \%$ of the respondents), with instructions in Greek and English (78.20\%), bearing phrases and sketches (64.33\%) and a lid opening with foot help $(65.36 \%)$. However, because of the large number of combinations and design complexity, we did not include a positive message or a thanking phrase in the design of the bins. A total of $46.4 \%$ of the phrases contained the word "environment" and 31.6\% the word "thank" or "thanks", while $40 \%$ of them had an encouragement message (Figure S4d).

\subsection{Validation Stage}

As described in the previous section, the exploratory stage of the research resulted in the 12 cards produced, which were evaluated by 430 participants (age: $M=39.38$, $S D=15.344$; gender: $42.6 \%$ male and $57.4 \%$ female) randomly selected with personal interviews. Based on the scores they provided (ranging from 1 to 6), the most preferable options were selected.

The paper recycling bins 5 and 4 (Figure 3) received a total score of $1754(M=4.08)$ and 1697 $(M=3.95)$ points, respectively (see Table S1). The Wilcoxon Signed Rank test indicated that these bins are leading with a statistically significant difference compared to the third one in rank (paper recycling bin 1: $M=3.51)$ and thus all the rest $(\mathrm{z}=-3.835, p<0.001$ and $\mathrm{z}=-3.370, p=0.001$, respectively).
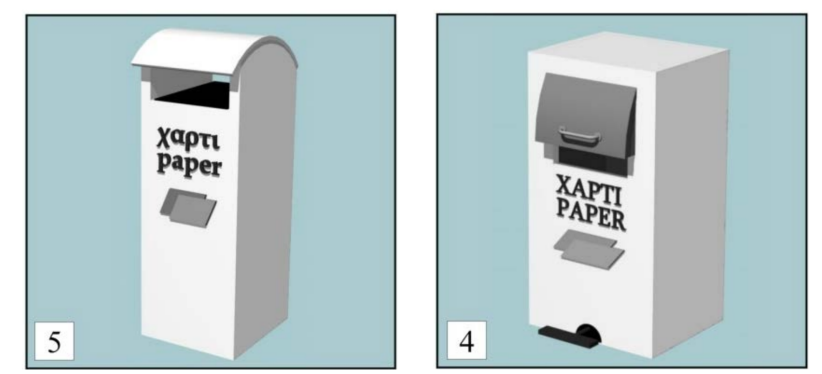

Figure 3. The preferred paper recycling bins according to the town residents. 
The plastic recycling bins 4 and 5 (Figure 4 ) received a total score of $1740(M=4.05)$ and 1738 points $(M=4.04)$, respectively (see Table S2). The Wilcoxon Signed Rank test indicated that these bins are leading with a statistically significant difference when compared to the third one in rank (plastic recycling bin 6: $M=3.62)$ and thus all the rest $(\mathrm{z}=-3.665, p<0.001$ and $\mathrm{z}=-3.413, p=0.001$, respectively).

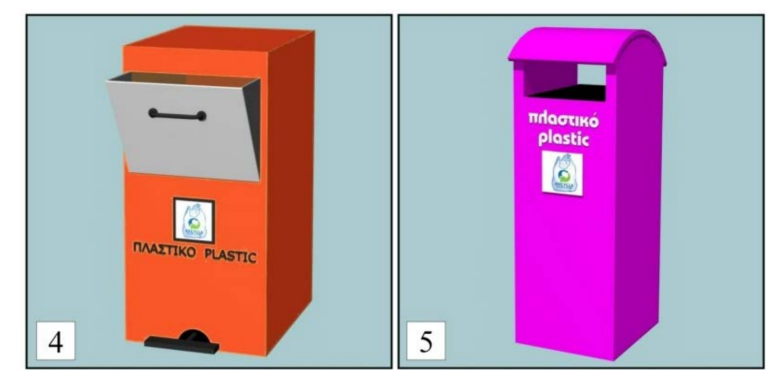

Figure 4. The preferred plastic recycling bins according to the town residents.

The package recycling bin 2 (Figure 5) received a total score of 1756 points $(M=4.08$ ), (see Table S3). The Wilcoxon Signed Rank test indicated that this bin is leading with a statistically significant difference when compared to the second one in rank (package recycling bin 5: $M=3.75$ ) and thus all the rest $(\mathrm{z}=-2.734, p=0.006)$.

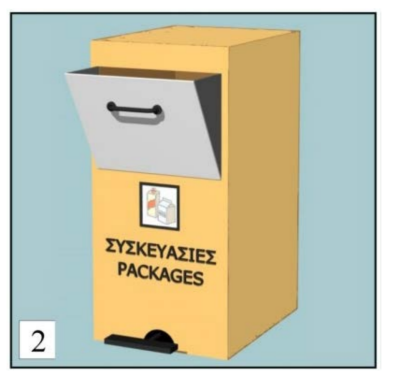

Figure 5. The preferred package recycling bin according to the town residents.

The aluminium recycling bins 5, 6, and 4 (Figure 6) received a total score of $1596(M=3.71), 1587$ $(M=3.69)$, and $1583(M=3.68)$ points, respectively (see Table $S 4)$. The Wilcoxon Signed Rank test indicated that the bins 5 and 6 are leading with a statistically significant difference when compared to the fourth one in rank (aluminium recycling bin 1: $M=3.41$ ) and thus all the rest $(z=-2.171, p=0.030$ and $\mathrm{z}=-2.099, p=0.036$, respectively), apart from the bin $4(\mathrm{z}=-1.881, p=0.06)$.
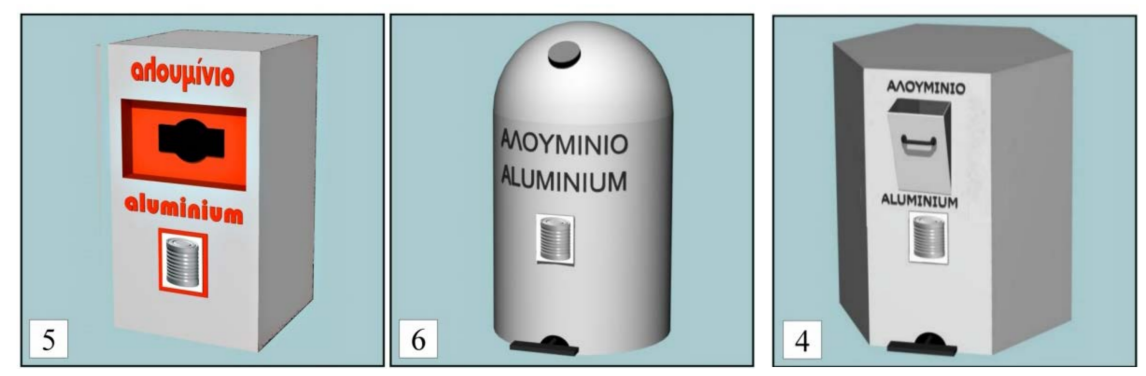

Figure 6. The preferred aluminium recycling bins according to the town residents.

The mixed glass recycling bins 3, 4, and 1 (Figure 7a) received a total score of $1652(M=3.84)$, $1631(M=3.79)$, and $1561(M=3.63)$ points, respectively (see Table S5). The Wilcoxon Signed Rank 
test indicated that these bins are leading with a statistically significant difference when compared to the fourth one in rank (the mixed glass recycling bin 2: $M=3.37)$ and thus all the rest $(\mathrm{z}=-3.547$, $p<0.001, \mathrm{z}=-3.193, p=0.001$ and $\mathrm{z}=-2.283, p=0.022$, respectively).

The clear glass recycling bins 4,3 , and 1 (Figure $7 b$ ) received a total score of $1641(M=3.82), 1622$ $(M=3.77)$, and $1571(M=3.65)$ points, respectively (see Table S6). The Wilcoxon Signed Rank test indicated that these bins are leading with a statistically significant difference when compared to the fourth one in rank (the clear glass recycling bin 2: $M=3.44$ ) and thus all the rest $(z=-2.720, p=0.007$ and $\mathrm{z}=-2.596, p=0.009$, respectively), apart from the bin $1(\mathrm{z}=-1.744, p=0.081)$.

The brown glass recycling bins 3, 4, and 2 (Figure 7c) received a total score of $1621(M=3.77)$, $1581(M=3.68)$, and $1541(M=3.58)$ points, respectively (see Table S7). The Wilcoxon Signed Rank test indicated that these bins are not leading with a statistically significant difference when compared to the fourth one in rank (the brown glass recycling bin 1: $M=3.52$ ). However, the brown glass recycling bin 1 was found to be leading with a statistically significant difference when compared to the brown glass recycling bin $5(\mathrm{z}=-3.887, p<0.001)$.

The green glass recycling bins 4,1 , and 3 (Figure $7 \mathrm{~d}$ ) received a total score of $1596(M=3.71), 1568$ $(M=3.65)$, and $1563(M=3.63)$ points, respectively (see Table S8). The Wilcoxon Signed Rank test indicated that these bins are not leading with a statistically significant difference when compared to the fourth one in rank (the green glass recycling bin 2: $M=3.57$ ). Also, the green glass recycling bin 2 was found to be leading with a statistically significant difference when compared to the green glass recycling bin $5(\mathrm{z}=-3.777, p<0.001)$.
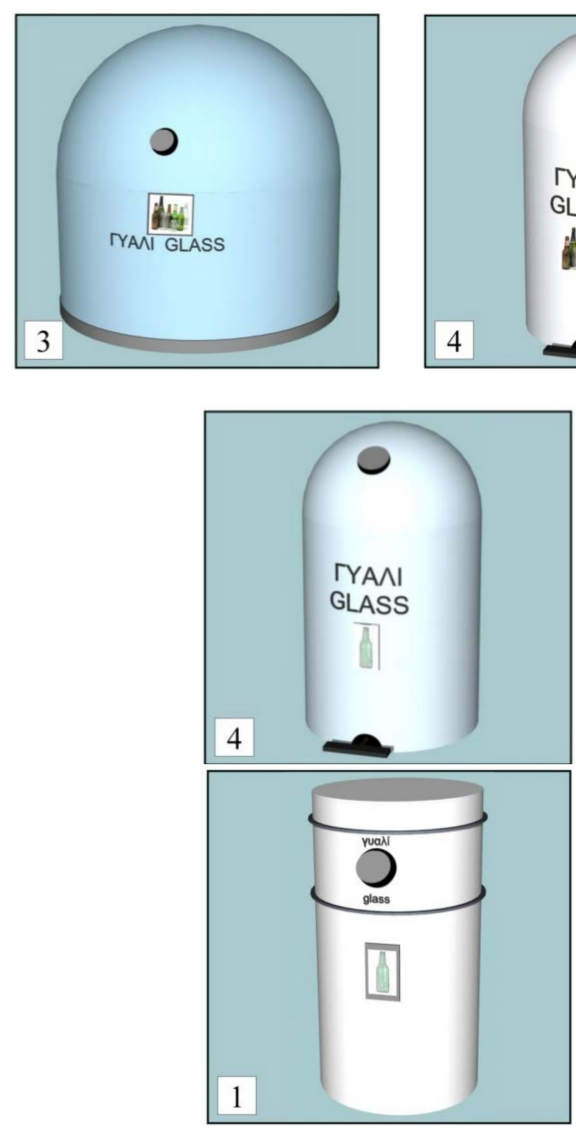

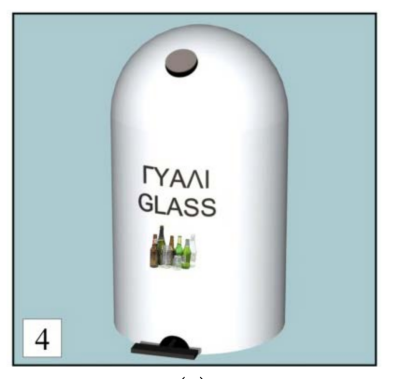

(a)

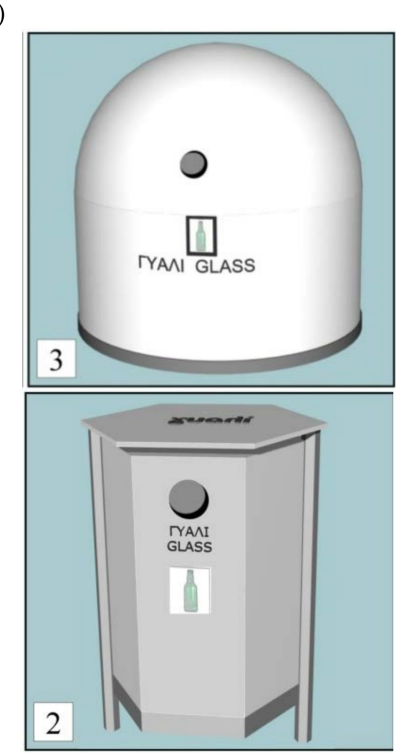

(b)

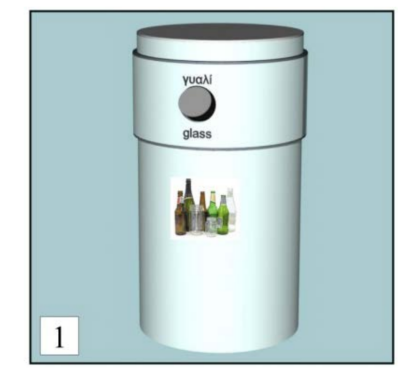



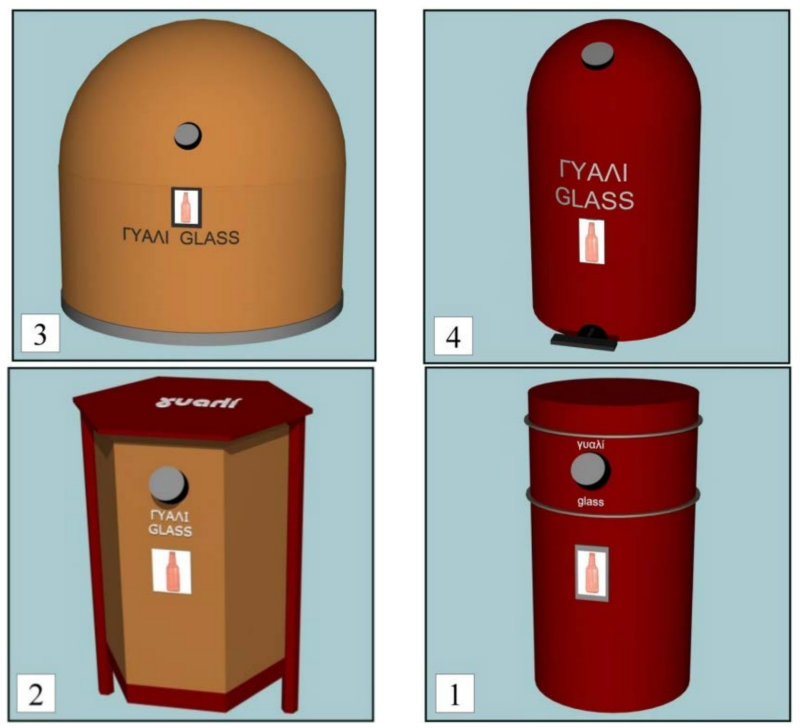

(c)
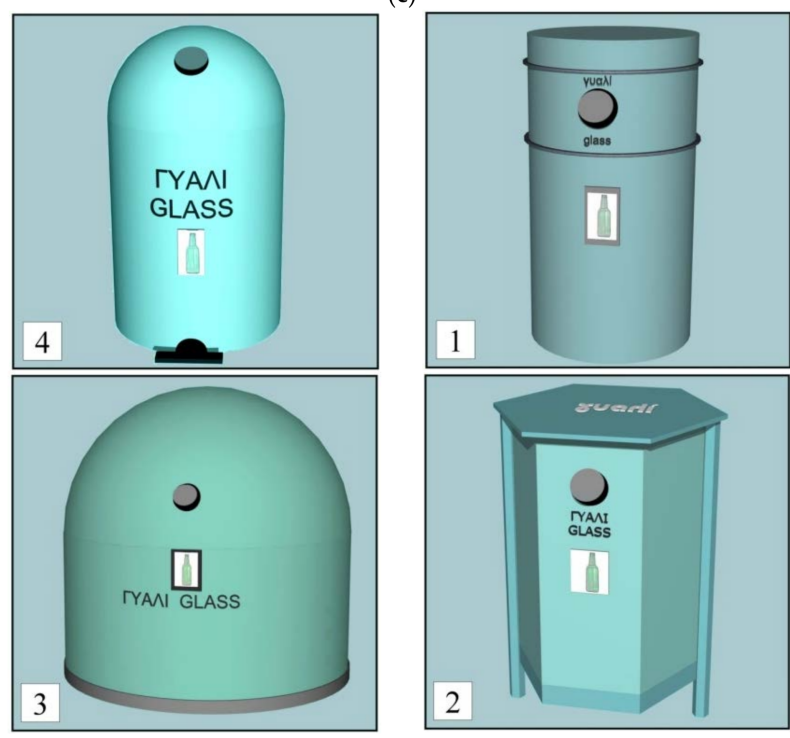

(d)

Figure 7. The preferred (a) mixed; (b) clear; (c) brown; (d) green glass recycling bins according to the town residents.

The compostables bins 2, 3, 1, and 4 (Figure 8) received a total score of $1629(M=3.79), 1531$ $(M=3.56), 1506(M=3.50)$, and $1503(M=3.50)$ points, respectively (see Table S9). The Wilcoxon Signed Rank test indicated that the bin 2 is leading with a statistically significant difference when compared to the bins 1 and $4(\mathrm{z}=-2.254, p=0.024$ and $\mathrm{z}=-2.181, p=0.029$, respectively), but not when compared to the bin $3(\mathrm{z}=-1.852, p=0.064)$. 

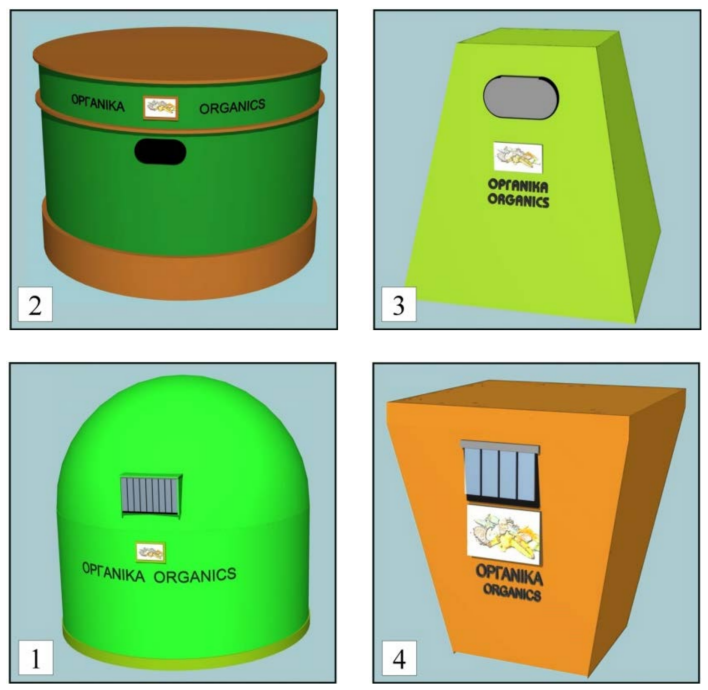

Figure 8. The preferred compostables recycling bins according to the town residents.

The commingled recyclables bins 5 and 2 (Figure 9) received a total score of $1678(M=3.90)$ and $1642(M=3.82)$ points, respectively (see Table S10). The Wilcoxon Signed Rank test indicated that these bins are leading with a statistically significant difference when compared to the third one in rank (recyclables bin 1: $M=3.48)$ and therefore all the rest $(\mathrm{z}=-3.146, p=0.002$ and $\mathrm{z}=-2.777, p=0.005$, respectively).
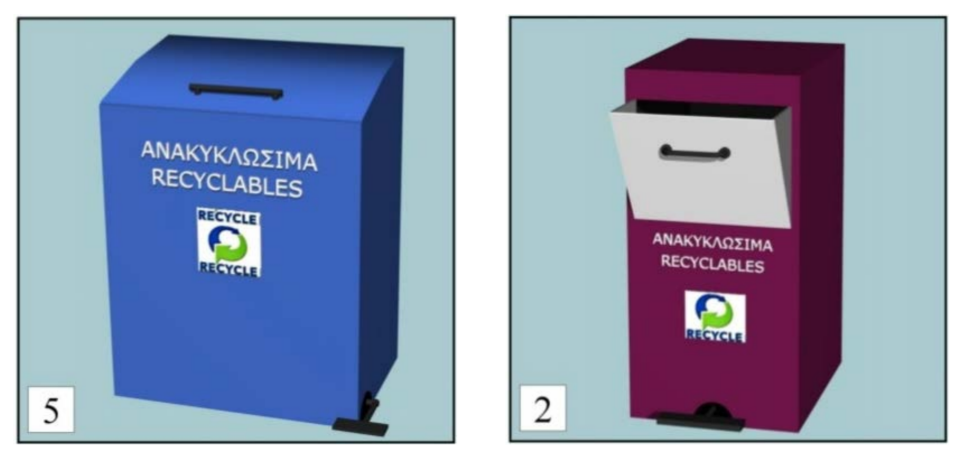

Figure 9. The preferred commingled recycling bins according to the town residents.

The waste bins 5 and 4 (Figure 10) received a total score of $1665(M=3.87)$ and $1641(M=3.82)$ points, respectively (see Table S11). The Wilcoxon Signed Rank test indicated that the bin 5 is leading with a statistically significant difference when compared to the third one in rank (waste bin 1: $M=3.57$ ) and thus all the rest $(\mathrm{z}=-2.099, p=0.036)$, but not when compared to the waste bin 4 .
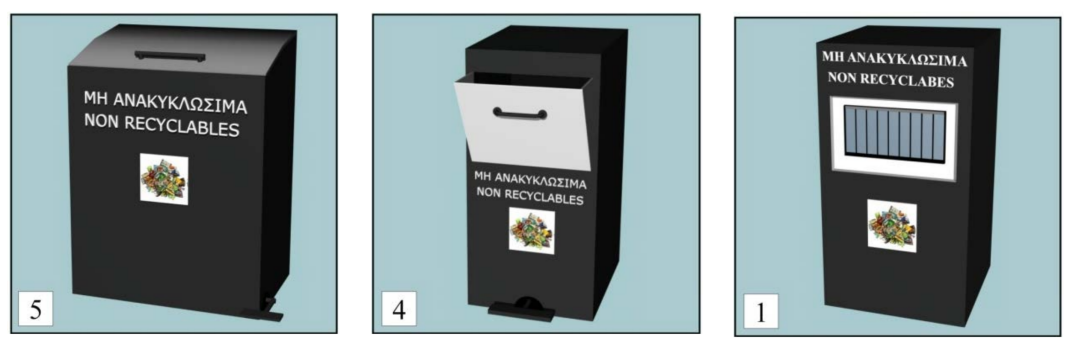

Figure 10. The preferred waste bins according to the town residents. 
The multi-bins 2, 5, and 6 (Figure 11) received a total score of $1641(M=3.82), 1621(M=3.77)$, and $1530(M=3.56)$ points, respectively (see Table S12). The Wilcoxon Signed Rank test indicated that the multi-bin 2 is leading with a statistically significant difference when compared to the multi-bin 6 $(\mathrm{z}=-1.999, p=0.046)$, but not from the multi-bin $5(\mathrm{z}=-0.134, p=0.893)$.
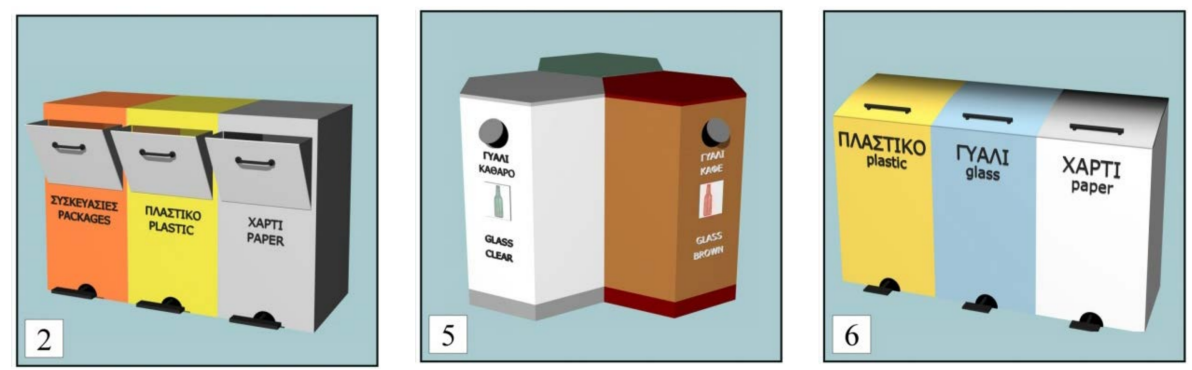

Figure 11. The preferred recycling multi-bins according to the town residents.

\section{Discussion}

The results of our research provide valuable insights into public preferences for recycling bins' properties in order to increase engagement and participation. In light of the limited research in the field, these findings, as well as the methodological approach, could gain greater attention and contribute to the effective and efficient implementation of recycling schemes.

Our findings indicate that the public tends to identify and connect the colour of the bin with the colour of the recyclable material, i.e., they associate paper with white and grey colours, aluminium with metallic grey, clear glass with white, brown glass with brown, blue-green glass with light blue-green, and organics with green and brown colours. When there is no defined colour for the material such as plastic or packages, the public selects various hues of orange, yellow, or purple. Results of a web survey conducted in Democritus University of Thrace, Greece, demonstrated that students would prefer the yellow coloured bin for the recycling of used plastic water bottle [82]. The bright yellow recycling bin covers increased the food waste sorting rates with low contamination according to an experimental study [83]. However, the respondents did not select the blue colour, which is the prevalent colour for paper in many countries. On the contrary, they would prefer this colour for the comingled recyclables bin, which indicates a possible influence of the "blue bin" (green-dot) programme introduced in many Greek cities for packages. A case study revealed that a green and secondly, blue versus red and grey recycling bin mostly triggered the recycling behaviour [84]. A two-coloured bin is another feasible option. Given that brown and green are the most common colours for organics bins in many countries, the combination of both would make the bins distinct and easily recognisable. Similarly, the use of two colours in the design of the recycling bin for aluminium cans such as metallic grey and orange would make it stand out from the paper bin, particularly when the latter has the same shape. The black colour was connected with trash as is the case in many of the countries listed in Table 1.

In addition, the public prefers special drop slots and lids on recycling bins for each material, paper, cans, packages, or bottles, which, according to a survey [85], improve recycling compliance. Generally, the covered recycling bins attracted the public preference despite the prevalence of the open-top bins, which could contribute to the reduction of litter generation [86].

The rectangular bin seems to be the most attractive shape with the exception of bins for glass and organics. The bell-shaped and cylindrical bins are preferable for glass, and the cylindrical and inverted or not truncated square pyramid bins are the most preferable shapes for compostables. Prismatic bins also attract residents' preferences. However, other criteria such as convenient lifting, emptying, or cleaning could help the waste services make the best choice selection.

Rectangular multi-bins with an appropriate colour and lids represent the public's choice. Two or three compartment multi-bins with signage located next to a non-recyclables bin seem to 
decrease recycling contamination [87]. Furthermore, motivational signs above the recycling bins gained a higher number of deposits [88] and a green bin sticker significantly increased the food waste recycling rates [89].

Finally, a positive message, including the words "environment", "thank", and "recycling", might encourage occasional but also conventional recyclers to continue. Previous research indicated that encouraging signs could be a simple and low cost method to enhance recycling [90], and a recycling bin which rewarded users with smiles and sounds or points increased recycling rates [91,92]. Moreover, a BinCam system motivated the users to change their food waste and recycling behaviour by uploading the households' recycling achievements on social media [93].

\section{Conclusions}

This study attempted to shed light on the design variables of recycling bins that the recycling actors should take into account in order to promote, facilitate, and encourage recycling. As a result of the limited research in the field, the novelty of this paper lies in that it suggests advice on: (i) a particular colour for the bin, the lid, or signage of the bin of each recyclable material; (ii) specific bin and multi-bin shapes; and (iii) a reward phrase including the words "environment", "thank", and "recycling".

General conclusions arising from the present results demonstrate that: (i) the public preferences do not always coincide with the top-down decision making in relation to the recycling bins design; (ii) people usually connect the colour of recycling items with the recycling bin colour; and (iii) public participation in the designing of recycling facilities could increase willingness to recycle.

Our recommendations and methodological approach could help instigate further discussion about the design of recycling bins, and open up opportunities for future research, particularly on applying experimental methods to provide concrete evidence about what people really do and what bins contribute to a higher recycling performance. Moreover, the findings should be validated for different countries and regions.

Supplementary Materials: The following are available online at http:/ /www.mdpi.com/2071-1050/10/4/1240/s1, Figure S1: Paper recycling bins in Greece; Figure S2: Recycling bins at recycling stations in Greek cities; Figure S3: The Microsoft colour palette used in this work; Figure S4: Preference for recycling bins' construction and design properties; Figure S5: Paper recycling bin preferences; Figure S6: Plastic recycling bin preferences; Figure S7: Package recycling bin preferences; Figure S8: Aluminium, can recycling bin preferences; Figure S9: Glass recycling bins' preferences; Figure S10: Organics recycling bin preferences; Figure S11: Comingle recyclables bin preferences; Figure S12: Waste bin preferences; Figure S13: Multi-bin type preferences; Figure S14: Six paper recycling bins designed from the findings of the exploratory stage; Figure S15: Six plastic recycling bins designed from the findings of the exploratory stage; Figure S16: Six package recycling bins designed from the findings of the exploratory stage; Figure S17: Six aluminium can recycling bins designed from the findings of the exploratory stage; Figure S18a: Six mixed glass recycling bins designed from the findings of the exploratory stage; Figure S18b: Six clear glass recycling bins designed from the findings of the exploratory stage; Figure S18c: Six brown glass recycling bins designed from the findings of the exploratory stage; Figure S18d: Six blue, green glass recycling bins designed from the findings of the exploratory stage; Figure S19: Six organics recycling bins designed from the findings of the exploratory stage; Figure S20: Six recyclables bins designed from the findings of the exploratory stage; Figure S21: Six waste bins designed from the findings of the exploratory stage; Figure S22: Six multi-bins designed from the findings of the exploratory stage; Table S1: Votes for each paper recycling bin; Table S2: Votes for each plastic recycling bin; Table S3: Votes for each package recycling bin; Table S4: Votes for each aluminium recycling bin; Table S5: Votes for each mixed glass recycling bin; Table S6: Votes for each clear glass recycling bin; Table S7: Votes for each brown glass recycling bin; Table S8: Votes for each green glass recycling bin; Table S9: Votes for each organics recycling bin; Table S10: Votes for each commingled recycling bin; Table S11: Votes for each waste bin; Table S12: Votes for each multi-bin.

Acknowledgments: This work was funded by the Engineers and Public Constructors Pension Fund, which is a periodic funding for independent research by faculty members of Engineering Schools in Greece. The authors are grateful to all participants in this research.

Author Contributions: Kiriaki M. Keramitsoglou collected the data, performed the analysis, and wrote the paper. Konstantinos P. Tsagarakis conceived and designed the research and conducted the overall supervision.

Conflicts of Interest: The authors declare no conflict of interest. 


\section{References}

1. Withers, J. Living: Designs on Your Dustbin. Available online: http://www.independent.co.uk/life-style/1 iving-designs-on-your-dustbin-1304066.html (accessed on 23 August 2017).

2. Chappells, H.; Shove, E. The dustbin: A study of domestic waste, household practices and utility services. Int. Plan. Stud. 1999, 4, 267-280. [CrossRef]

3. Hobson, K. Bins, bulbs, and shower timers: On the 'techno-ethics' of sustainable living. Ethics Place Environ. 2006, 9, 317-336. [CrossRef]

4. Jelsma, J. Innovating for sustainability: Involving users, politics and technology. Innov. Eur. J. Soc. Sci. Res. 2003, 16, 103-116. [CrossRef]

5. Soper, K. Re-thinking the 'good life': The citizenship dimension of consumer disaffection with consumerism. J. Consum. Cult. 2007, 7, 205-229. [CrossRef]

6. Jutta, H. The environment on holidays or how a recycling bin informs us on the environment. J. Doc. 2011, $67,823-839$.

7. Fiorillo, D. Household waste recycling: National survey evidence from Italy. J. Environ. Plan. Manag. 2013, 56, 1125-1151. [CrossRef]

8. Malakahmad, A.; Nasir, C.M.; Za'im Zaki, M.; Kutty, S.R.M.; Isa, M.H. Solid waste characterization and recycling potential for university technology petronas academic buildings. Am. J. Environ. Sci. 2010, 6, 422-427. [CrossRef]

9. Yoreh, T.; Horne, R. Recycling in Jerusalem: Right or privilege? Local Environ. 2014, 19, 417-432. [CrossRef]

10. Suttibak, S.; Nitivattananon, V. Assessment of factors influencing the performance of solid waste recycling programs. Resour. Conserv. Recycl. 2008, 53, 45-56. [CrossRef]

11. Coggins, C. Waste prevention-An issue of shared responsibility for UK producers and consumers: Policy options and measurement. Resour. Conserv. Recycl. 2001, 32, 181-190. [CrossRef]

12. Lyas, J.K.; Shaw, P.J.; van Vugt, M. Kerbside recycling in the London Borough of Havering: Progress and priorities. Resour. Conserv. Recycl. 2005, 45, 1-17. [CrossRef]

13. Wang, F.S.; Richardson, A.J.; Roddick, F.A. Relationships between set-out rate, participation rate and set-out quantity in recycling programs. Resour. Conserv. Recycl. 1997, 20, 1-17. [CrossRef]

14. Williams, I.D.; Taylor, C. Maximising household waste recycling at civic amenity sites in Lancashire, England. Waste Manag. 2004, 24, 861-874. [CrossRef] [PubMed]

15. Chong, A.; Karlan, D.; Shapiro, J.; Zinman, J. (Ineffective) messages to encourage recycling: Evidence from a randomized evaluation in Peru. World Bank Econ. Rev. 2015, 29, 180-206. [CrossRef]

16. McDonald, S.; Ball, R. Public participation in plastics recycling schemes. Resour. Conserv. Recycl. 1998, 22, 123-141. [CrossRef]

17. Smith, D.N.; Harrison, L.M.; Simmons, A.J. A survey of schemes in the United Kingdom collecting plastic bottles for recycling. Resour. Conserv. Recycl. 1999, 25, 17-34. [CrossRef]

18. Lakhan, C. Out of sight, out of mind: Issues and obstacles to recycling in Ontario's multi residential buildings. Resour. Conserv. Recycl. 2016, 108, 1-9. [CrossRef]

19. Williams, I.D.; Kelly, J. Green waste collection and the public's recycling behaviour in the Borough of Wyre, England. Resour. Conserv. Recycl. 2003, 38, 139-159. [CrossRef]

20. Perry, G.D.R.; Williams, I.D. The participation of ethnic minorities in kerbside recycling: A case study. Resour. Conserv. Recycl. 2007, 49, 308-323. [CrossRef]

21. Šauer, P.; Pařízková, L.; Hadrabová, A. Charging systems for municipal solid waste: Experience from the Czech Republic. Waste Manag. 2008, 28, 2772-2777. [CrossRef] [PubMed]

22. Robinson, G.M.; Read, A.D. Recycling behaviour in a London Borough: Results from large-scale household surveys. Resour. Conserv. Recycl. 2005, 45, 70-83. [CrossRef]

23. Wan, C.; Shen, G.Q.; Yu, A. The role of perceived effectiveness of policy measures in predicting recycling behaviour in Hong Kong. Resour. Conserv. Recycl. 2014, 83, 141-151. [CrossRef]

24. Chen, Y. Collecting waste textiles mainly through recycling bins. Wool Text. J. 2016, 44, 69-72.

25. Schüch, A.; Morscheck, G.; Lemke, A.; Nelles, M. Bio-waste recycling in Germany-Further challenges. Procedia Environ. Sci. 2016, 35, 308-318. [CrossRef]

26. Willman, K.W. Information sharing and curbside recycling: A pilot study to evaluate the value of door-to-door distribution of informational literature. Resour. Conserv. Recycl. 2015, 104, 162-171. [CrossRef] 
27. Mbuligwe, S.E. Institutional solid waste management practices in developing countries: A case study of three academic institutions in Tanzania. Resour. Conserv. Recycl. 2002, 35, 131-146. [CrossRef]

28. Malik, N.K.A.; Abdullah, S.H.; Manaf, L.A. Community participation on solid waste segregation through recycling programmes in Putrajaya. Procedia Environ. Sci. 2015, 30, 10-14. [CrossRef]

29. Perrin, D.; Barton, J. Issues associated with transforming household attitudes and opinions into materials recovery: A review of two kerbside recycling schemes. Resour. Conserv. Recycl. 2001, 33, 61-74. [CrossRef]

30. Thomas, C. Public understanding and its effect on recycling performance in Hampshire and Milton Keynes. Resour. Conserv. Recycl. 2001, 32, 259-274. [CrossRef]

31. Julia, A.F.; Diane, C.B. Recycling as a result of "cultural greening"? Int. J. Sustain. High. Educ. 2016, 17, 489-505.

32. McDonald, S.; Oates, C. Reasons for non-participation in a kerbside recycling scheme. Resour. Conserv. Recycl. 2003, 39, 369-385. [CrossRef]

33. Tonglet, M.; Phillips, P.S.; Bates, M.P. Determining the drivers for householder pro-environmental behaviour: Waste minimisation compared to recycling. Resour. Conserv. Recycl. 2004, 42, 27-48. [CrossRef]

34. Pattnaik, S.; Reddy, M.V. Assessment of municipal solid waste management in Puducherry (Pondicherry), India. Resour. Conserv. Recycl. 2010, 54, 512-520. [CrossRef]

35. Lakhan, C. Evaluating the effects of unit based waste disposal schemes on the collection of household recyclables in Ontario, Canada. Resour. Conserv. Recycl. 2015, 95, 38-45. [CrossRef]

36. Fan, K.H. The social challenges of involving the general publics in garbage separation and recycling in Chinese cities. Adv. Mater. Res. 2014, 878, 831-839. [CrossRef]

37. Byrne, S.; O'Regan, B. Attitudes and actions towards recycling behaviours in the Limerick, Ireland region. Resour. Conserv. Recycl. 2014, 87, 89-96. [CrossRef]

38. Lane, G.W.S.; Wagner, T.P. Examining recycling container attributes and household recycling practices. Resour. Conserv. Recycl. 2013, 75, 32-40. [CrossRef]

39. Mellon, R.C.; Tsagarakis, K.P. Assessment of implicit meaning in the design of graphic symbols for the control of recycled water use. Environ. Behav. 2006, 38, 689-706. [CrossRef]

40. Tsagarakis, K.P.; Mellon, R.C.; Stamataki, E.; Kounalaki, E. Identification of recycled water with an empirically derived symbol increases its probability of use. Environ. Sci. Technol. 2007, 41, 6901-6908. [CrossRef] [PubMed]

41. SI. The Swidish Institute. Sustainable Living: Living for the Future. 2012. Available online: http:/ / sharingswe den.se/wp-content/uploads/2015/06/Sustainable-living-in-Sweden-low-res.pdf (accessed on 14 April 2018).

42. Thaler, R.H.; Sunstein, C.R. A strategy for recycling: Change the recycling-bin-to-garbage-bin ratio. In Nudge: Improving Decisions About Health, Wealth, and Happiness; Penguin Books: London, UK, 2011. Available online: http:/ / nudges.org/2011/05/02/a-strategy-for-recycling-change-the-recyling-bin-to-garbage-binratio/ (accessed on 14 April 2018).

43. Chow, C.-F.; So, W.-M.W.; Cheung, T.-Y. Research and development of a new waste collection bin to facilitate education in plastic recycling. Appl. Environ. Educ. Commun. 2016, 15, 45-57. [CrossRef]

44. STEEEV. Recyling Bin Japan Metro. Available online: https://www.Flickr.Com/photos/steeev/5862478/i n/photostream/ (accessed on 23 August 2017).

45. Huang, C. Transparent Recycling Bins: Confronting Our Waste. Available online: https://www.Psfk.Com/2 007/08/transparent-recycling-bins-confronting-our-waste.Html (accessed on 23 August 2017).

46. Wandsworth. Be Clear about Recycling with New-Look Sacks. Available online: http://www.Wandsworth.G ov.Uk/news/article/11709/be_clear_about_recycling_with_new-look_sacks (accessed on 23 August 2017).

47. Elder, J.; Shape+colour. Magenta Foundation: “Flash Forward" Recycling Bins. Available online: https://sh apeandcolour.Wordpress.Com/2008/04/15/magenta-foundatin-flash-forward-recycling-bins/ (accessed on 23 August 2017).

48. Indiana-University. Iu News Room, “More Art, Less Trash" Artistic Recycling Bins to Be Installed on Campus. Available online: http:/ / newsinfo.Iu.Edu/news-archive/7902.Html (accessed on 23 August 2017).

49. Cahillane, J.; Slattery, S. Beautiful bins. Waste Age 2007, 38, 18-19.

50. Press, V.S. Israelis Go Gaga over Recycling. Available online: https://www.Israel21c.Org/israelis-go-gaga-o ver-recycling/ (accessed on 23 August 2017).

51. Meis, J.; Kashima, Y. Signage as a tool for behavioral change: Direct and indirect routes to understanding the meaning of a sign. PLoS ONE 2017, 12, e0182975. [CrossRef] [PubMed] 
52. Oirier, M.; Brain, R.; Barajas, E. Strategies to improve recycling in natural areas: Examples from Zion National Park. Department of Environment $\mathcal{E}$ Society; Zion National Park. Utah State University Extention Sustainability, National Park Service. 2013. Available online: https://digitalcommons.usu.edu/cgi/viewcontent.cgi?article $=1317 \&$ context=extension_curall (accessed on 14 April 2018).

53. Danberg-Ficarelli, M. Importance of signage. Common Ground Compost. com. 2017. Available online: http:/ / commongroundcompost.com/importance-of-signage/ (accessed on 14 April 2018).

54. ProEurope. The Green Dot Trademark. Available online: http://www.pro-e.org/the-green-dot-trademark (accessed on 14 April 2018).

55. ProEurope. Uniformity in Diversity, Brussels. Available online: http://www.Pro-e.Org/files/pro-europe producer-responsibility-in-action_web-version_final_150811.Pdf (accessed on 23 August 2017).

56. Athens-A $\theta \dot{v} \vee \alpha$. Municipality of Athens. Recycling Programme. Available online: https://www.Cityofathe ns.Gr/en/recycling-programme-0 (accessed on 23 August 2017).

57. HowtoGermany. All about Recycling in Germany. Germany Has Been Very Successful in Its Fight against Growing Garbage Heaps. But What Does This Mean for You? Available online: http:/ /www.Howtogerma ny.Com/pages/recycling.Html (accessed on 23 August 2017).

58. Look, M. Trash Planet: Germany. Available online: http://earth911.Com/earth-watch/trash-planet-germany/ (accessed on 23 August 2017).

59. Newcomers-Network. Recycling Rules. Available online: http://www.Newcomers-network.De/germany /newcomers-guide/housing/recycling_rules.Php (accessed on 23 August 2017).

60. Feisner, E.A. Colour How to Use Colour in Art and Design; Laurence King Publishing Ltd.: London, UK, 2006.

61. Toska, T.-F. Architectural Colour: Theory and Design; Kyriakidi Brothers: Thessaloniki, Greece, 1989.

62. Kelly, T.C.; Mason, I.G.; Leiss, M.W.; Ganesh, S. University community responses to on-campus resource recycling. Resour. Conserv. Recycl. 2006, 47, 42-55.

63. Mason, I.G.; Oberender, A.; Brooking, A.K. Source separation and potential re-use of resource residuals at a university campus. Resour. Conserv. Recycl. 2004, 40, 155-172.

64. Tonglet, M.; Phillips, P.S.; Read, A.D. Using the theory of planned behaviour to investigate the determinants of recycling behaviour: A case study from Brixworth, UK. Resour. Conserv. Recycl. 2004, 41, 191-214. [CrossRef]

65. Farzadkia, M.; Jorfi, S.; Akbari, H.; Ghasemi, M. Evaluation of dry solid waste recycling from municipal solid waste: Case of Mashhad City, Iran. Waste Manag. Res. 2012, 30, 106-112. [CrossRef] [PubMed]

66. Green-dotCyprus. How Should I Recycle? Available online: http://greendot.Com.Cy/en/public/how-sh ould-i-recycle (accessed on 23 August 2017).

67. Gotoh, S.; Tanaka, E.; Yonemura, Y. Source separation for resource recovery-State-of-the-art. Conserv. Recycl. 1979, 3, 305-317. [CrossRef]

68. Espinosa, R.M.; Turpin, S.; Polanco, G.; De laTorre, A.; Delfín, I.; Raygoza, I. Integral urban solid waste management program in a Mexican university. Waste Manag. 2008, 28, S27-S32. [CrossRef] [PubMed]

69. Ball, R. The bled symposium glass recycling by source separation from municipal wastes. Resour. Conserv. Recycl. 1990, 4, 63-75. [CrossRef]

70. Cimpan, C.; Maul, A.; Jansen, M.; Pretz, T.; Wenzel, H. Central sorting and recovery of MSW recyclable materials: A review of technological state-of-the-art, cases, practice and implications for materials recycling. J. Environ. Manag. 2015, 156, 181-199. [CrossRef] [PubMed]

71. Barnet. Household Waste and Recycling Bins. Available online: https://www.Barnet.Gov.Uk/citizen-home / rubbish-waste-and-recycling/household-recycling-and-waste/household-waste-and-recycling-bin-col lections.Html (accessed on 23 August 2017).

72. Chandler, N. The bin stops here. Waste Age 2004, 35, 22-23.

73. Hellenic Recovery Recycling Corporation. Which Packaging Materials Are Recyclable. Available online: http: / / www.Herrco.Gr / default.Asp?Siteid=1\&pageid=12\&langid=2 (accessed on 23 August 2017).

74. Woodard, R.; Harder, M.K.; Bench, M.; Philip, M. Evaluating the performance of a fortnightly collection of household waste separated into compostables, recyclates and refuse in the south of England. Resour. Conserv. Recycl. 2001, 31, 265-284. [CrossRef]

75. Mee, N.; Clewes, D.; Phillips, P.S.; Read, A.D. Effective implementation of a marketing communications strategy for kerbside recycling: A case study from Rushcliffe, UK. Resour. Conserv. Recycl. 2004, 42, 1-26. [CrossRef] 
76. Read, M.; Gregory, M.K.; Phillips, P.S. An evaluation of four key methods for monitoring household waste prevention campaigns in the UK. Resour. Conserv. Recycl. 2009, 54, 9-20. [CrossRef]

77. Uta, H.-C. If you build it, will they sort it? Compost collection in the academic library learning commons. Library Manag. 2016, 37, 340-351.

78. Randall, T.; Terwiesch, C.; Ulrich, K.T. Principles for user design of customized products. Calif. Manag. Rev. 2005, 47, 68-85.

79. Randall, T.; Terwiesch, C.; Ulrich, K.T. User design of customized products. Mark. Sci. 2007, 26, $268-280$. [CrossRef]

80. Iyengar, S.S.; Lepper, M.R. When choice is demotivating: Can one desire too much of a good thing? J. Personal. Soc. Psychol. 2000, 79, 995-1006. [CrossRef]

81. Oulasvirta, A.; Hukkinen, J.P.; Schwartz, B. When more is less: The paradox of choice in search engine use. In Proceedings of the 32nd International ACM SIGIR Conference on Research and Development in Information Retrieval, Boston, MA, USA, 19-23 July 2009; ACM: New York, NY, USA, 2009; pp. 516-523.

82. Kalatzi, I.K.; Nikellis, A.E.; Menegaki, A.N.; Tsagarakis, K.P. The preferred bin colour for recycling plastic bottles: Evidence from a student's sample. Prog. Ind. Ecol. 2015, 9, 256-268. [CrossRef]

83. Lin, Z.; Wang, X.; Li, C.; Gordon, M.; Harder, M. Visual prompts or volunteer models: An experiment in recycling. Sustainability 2016, 8, 458. [CrossRef]

84. Montazeri, S.; Gonzalez, R.D.; Yoon, C.; Papalambros, P.Y. Color, Cognition, and Recycling: How the Design of Everyday Objects Prompt Behavior Change. In Proceedings of the International Design Conference, Dubrovnik, Croatia, 21-24 May 2012; pp. 1363-1368.

85. Duffy, S.; Verges, M. It matters a hole lot: Perceptual affordances of waste containers influence recycling compliance. Environ. Behav. 2009, 41, 741-749. [CrossRef]

86. Wagner, T.P.; Broaddus, N. The generation and cost of litter resulting from the curbside collection of recycling. Waste Manag. 2016, 50, 3-9. [CrossRef] [PubMed]

87. Andrews, A.; Gregoire, M.; Rasmussen, H.; Witowich, G. Comparison of recycling outcomes in three types of recycling collection units. Waste Manag. 2013, 33, 530-535. [CrossRef] [PubMed]

88. Verdonk, S.; Chiveralls, K.; Dawson, D. Getting wasted at WOMADelaide: The effect of signage on waste disposal. Sustainability 2017, 9, 344. [CrossRef]

89. Shearer, L.; Gatersleben, B.; Morse, S.; Smyth, M.; Hunt, S. A problem unstuck? Evaluating the effectiveness of sticker prompts for encouraging household food waste recycling behaviour. Waste Manag. 2017, 60, 164-172. [CrossRef] [PubMed]

90. Becker, C.M.; Ayscue, E.; Brockett, S.J.; Scarola, G.; Kelley, T. Initiating sustainable behavior: Feel good for doing good. Electron. Green J. 2014, 1, 1-12.

91. Berengueres, J.; Alsuwairi, F.; Zaki, N.; Ng, T. Emo-bin: How to recycle more by using emoticons. In Proceedings of the 8th ACM/IEEE International Conference on Human-Robot Interaction (HRI), Tokyo, Japan, 3-6 March 2013; IEEE Press: Piscataway, NJ, USA, 2013; pp. 397-398. [CrossRef]

92. Tomari, R.; Kadir, A.A.; Zakaria, W.N.W.; Zakaria, M.F.; Wahab, M.H.A.; Jabbar, M.H. Development of reverse vending machine (RVM) framework for implementation to a standard recycle bin. Procedia Comput. Sci. 2017, 105, 75-80. [CrossRef]

93. Thieme, A.; Comber, R.; Miebach, J.; Weeden, J.; Kraemer, N.; Lawson, S.; Olivier, P. “We've bin watching you": Designing for reflection and social persuasion to promote sustainable lifestyles. In Proceedings of the SIGCHI Conference on Human Factors in Computing Systems, Austin, TX, USA, 5-10 May 2012; ACM: New York, NY, USA, 2012; pp. 2337-2346.

(C) 2018 by the authors. Licensee MDPI, Basel, Switzerland. This article is an open access article distributed under the terms and conditions of the Creative Commons Attribution (CC BY) license (http://creativecommons.org/licenses/by/4.0/). 